\title{
A Study on Celebrity Cosmetic Brand Content Analysis and Social Media Engagement: In The Case of Fenty BeAuty's Product
}

\author{
Anishametra Saravanan* \\ UCSI University, Malaysia \\ *anishametra08@gmail.com \\ Wardatul Hayat Adnan \\ Universiti Teknologi MARA, Malaysia \\ wardatul@uitm.edu.my
}

\begin{abstract}
The cosmetic industry has seen an explosive growth in the past few years. Although many beauty conglomerates are leading the forefront of the global cosmetics industry, the beauty standards by them set are usually Eurocentric in nature. However, rapid changes with Fenty Beauty first appearance in cosmetic industry. The brand took the world by storm when they introduced an idea that resonated with a large community of makeup enthusiasts. Despite being in its infancy stage, the brand has made plenty of ripples to change the industry for the better through its inclusivity approach. The present study aims to gain a greater understanding on the brand's social media engagement with their followers on Instagram, Twitter, Facebook and YouTube as well as classifying the brand's followers according to the social identity theory. Qualitative content analysis was applied in the present study to gain a better understanding of Fenty Beauty's social media engagement efforts with their followers. The coding scheme implemented is adopted of Bales' Interaction Process Analysis (IPA) Model to study how followers of the brand react to social media posts made by Fenty Beauty. The findings of the present study will be useful to the cosmetic industry as it will proof the potential of social media as a powerful marketing tool. The findings of the present research will be beneficial to companies in the cosmetic industry and marketing practitioners provides an insight as to what motivates online users to engage and interact with a brand.
\end{abstract}

Keywords: Celebrity cosmetic brand, content analysis; Interaction Process Analysis (IPA) Model; Fenty Beauty; social media engagement, Malaysia

\section{INTRODUCTION}

The cosmetic industry has seen an explosive growth in the past few years. According to Reuters, global cosmetics products market is predicted to reach USD 805.61 billion by the year 2023 (Reuters, 2018). The growth of the industry is attributed to the demand of beauty 
and personal care products, due to an upsurge in the aging population (PR Newswire, 2018). Additionally, the growth of global market economies, rising demands of skin products and evolving lifestyles, is due to the substantial rise in disposable incomes over the past decade (Rajput, 2016). On September 2017, Fenty Beauty by Rihanna was born amidst the chaos of New York Fashion Week (Abouarrage, 2017). Searches for the word "fenty" accelerated by $916 \%$ during the month of the launch (Bailis, 2017). Fenty Beauty's Instagram account was able to reach $10.41 \%$ fan engagement while most beauty brands have a $1 \%$ engagement rate on average (Sharma, 2018).

Fenty Beauty's engagement efforts towards their followers are commendable, even though the brand is only at its infancy stage. The brand consistently curates' posts to be shared on various online platforms. The brand's marketing team is credited for creating social media content that users find relatable and enticing (Wall, 2019). These days, great significance is put on a brand's social media presence. Great adoptions of advancements of the Internet, mobile technologies and social media have resulted in high levels of customer-brand engagements (Wirtz, 2013). Therefore, the present study purposes to gain a greater understanding on the brand's social media engagement efforts with their followers on Instagram, Twitter, Facebook and YouTube. The present study draws on social identity theory to learn about how followers of a brand are classified by studying their interaction with the brand.

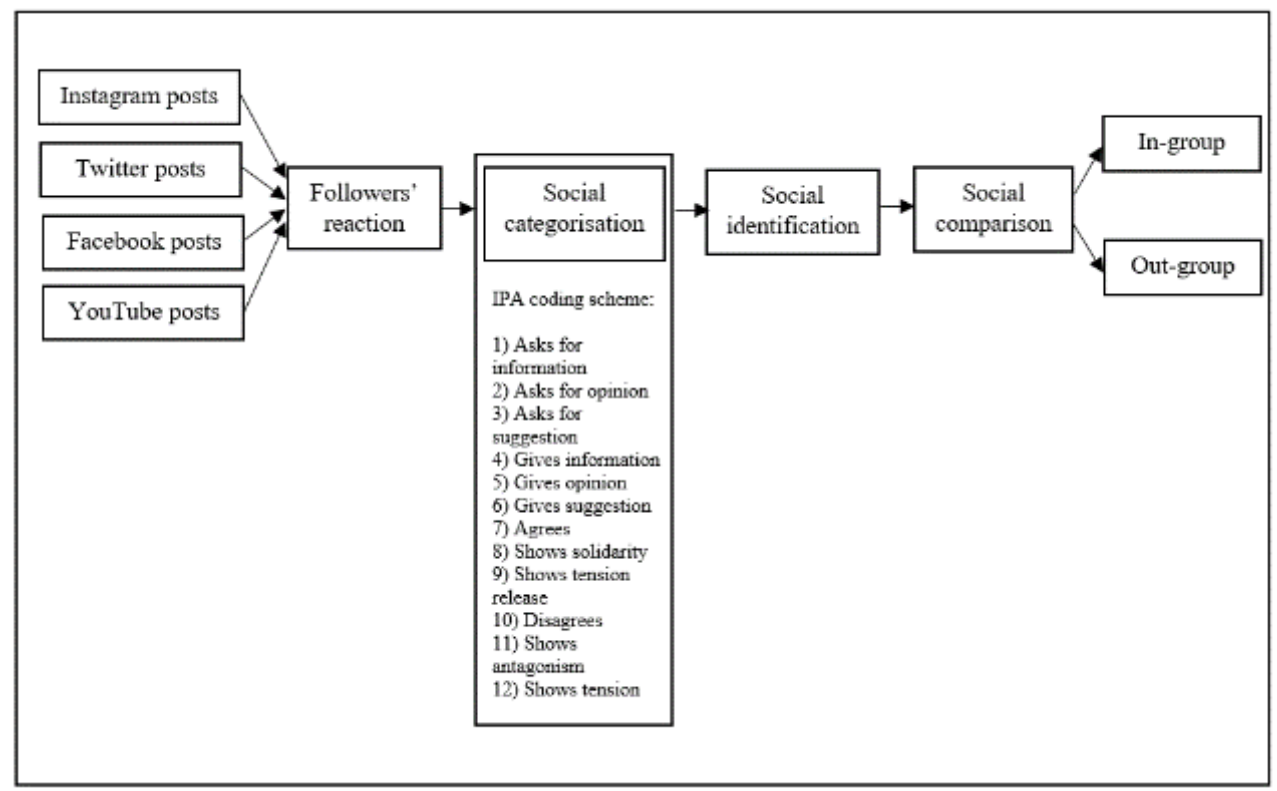

Figure 1: Proposed Conceptual Framework with Adopted Theories Guiding the Study

The IPA model has been modified and utilized in various journal articles to study online social interactions (i.e. Online and Face-to-Face Group Interaction Processes Compared Using Bales' Interaction Process Analysis (IPA) by Fahy (2006) and The Role of Emotions in Online Information Seeking and Sharing: A Case Study of Consumer Awareness by Savolainen (2015). Nevertheless, the IPA model have almost never been within the cosmetics industry. Limited qualitative studies on the cosmetic industry were conducted from a social media engagement angle. Social Media, Social Me: A Content Analysis of Beauty Companies' Use of Facebook in Marketing and Branding, analysed the type of content beauty companies post 
on their Facebook page and studied the brand's engagement with their followers (Shen \& Bissell, 2013). Besides, only few researches have been conducted about the present brand (Zelealem, 2017; Walters, 2018).

The final proposed conceptual framework for the present study integrates the theoretical framework and proposed conceptual framework. The data collected from four social media platforms will be recorded and tabulated. The data will then be categorized and identified into their respective codes. A comparison of the data will be conducted, and the followers' reaction are categorized as in-group or out-group. Objectives of the present study withdrawn from the framework of Figure 1 are as follows:

RO1: To study the followers' reaction to Fenty Beauty's posts on their official Instagram account.

RO2: To identify if the followers' reaction to Fenty Beauty's Instagram postings are categorized as in-group or out-group.

R03: To study the followers' reaction to Fenty Beauty's tweets on their official Twitter account.

RO4: To identify if the followers' reaction to Fenty Beauty's tweets are categorized as in-group or out-group.

RO5: To study the followers' reaction to Fenty Beauty's posts on their official Facebook account.

RO6: To identify if the followers' reaction to Fenty Beauty's Facebook postings are categorized as in-group or out-group.

RO7: To study the followers' reaction to Fenty Beauty's videos posted on their official YouTube account.

RO8: To identify if the followers' reaction to Fenty Beauty's YouTube videos are categorized as in-group or out-group.

RO9: To determine the most effective SNS that accommodates and encourages the interaction between Fenty Beauty and their followers, based on the number of brand posts and frequency of engagement received from followers.

\section{LITERATURE REVIEW}

The rise of the cosmetic industry has led many celebrities to jump on the opportunity to create a makeup line or brand of their own. Celebrities such as Rosie Huntington-Whiteley (for Autograph), Mariah Carey (MAC Cosmetics) and Gigi Hadid (Maybelline) are examples of personalities collaborating with brands to launch their makeup line. These lines are usually released for a limited time as the parent companies prioritize looking for new celebrities to work with (Kaur, 2018).

While some celebrities starting a makeup line with the help of a cosmetic company, others favor creating their own beauty brand from scratch. Reality TV star Kylie Jenner began her creative venture into the industry when she released the Kylie Cosmetics Lip Kit line in 2015 which sold out within minutes of its release online (Shi, 2018). Since then, Kylie has released plenty of other makeup products through her brand. As of 2017, the brand is reportedly valued at $\$ 800$ million (Robehmed, 2018). 
The digital shift in customer engagement is incredibly profound and has changed the cosmetic industry for good. According to Suzy Ross, senior advisor at Accenture, brand owners these days prioritize building a direct relationship with their customers and usually place their customers at the heart of the product experience (Simpson \& Craig, 2018).

Beauty brands engage their followers through bite-size makeup tutorials that shows off their beauty products and encourages UGC which creates organic ads to capture new customers (Barnhart, 2018). Social media influencers are hired by beauty brands as they influence the buying behaviour of big groups of people by voicing their opinions on a brand's product (Forbes, 2016). Premium cosmetic brands struggle when consumers prefer to purchase improved mass-market products due to the transparencies enabled by social media. This affects the sales of premium cosmetic brands and force them to partner with tech companies to meet the digital needs of the younger generation (Coady, 2018).

A wide spectrum of factors influences followers to interact and engage with the brands they are interested in. Six factors were identified that played a part in encouraging followers' interaction; vividness and variety of online content, brand interactivity, description of a product, information enriched with entertaining features and novelty of content posted (Farook \& Abeysekara, 2016). Due to the shift in the communication model being dominated by followers, some marketers think that it weakens mass marketing because posts need to be presented in a personal way to target every consumer's wants and needs (Constantinides, 2009). Annoyance with social media content may negatively affect followers' evaluation of the brand during their purchasing process (Hutter, Hautz, Dennhardt, \& Füller, 2013).

Instagram is considered as a notable engagement tool due the application's engagement rate of brands (measured by comments, likes and shares made by users) is at $4.2 \%$, making it 10 times higher than Facebook and 84 times more than Twitter (Phillips, 2018). Instagram offers brands and companies the opportunity to reflect on a posting by encouraging the usage of hashtags (Bergström \& Bäckman, 2013). Brands that use the application to build an emotional bond with their following are most likely to have a profitable relationship with their consumers (Gong, 2014). Some marketers struggle to produce interesting content and may find it challenging to compete with bigger brands (Jaakonmäki, Müller, \& vom Brocke, 2017). Some brands may also face the issue of Instagram Shadowban, which occurs when posts made by a brand do not appear in the search results, causing the brand to receive a lower engagement rate (Triberr, 2018.).

Twitter acts as a prominent channel that relies on topical content to relate to an audience and the usage of hashtags stimulates brand conversation with followers online (Soboleva, Burton, \& Khan, 2015). The platform's simple mobile interface is great for engagement and helps users instantly reach large audiences (Mueller, n.d.). Some brands may face challenges in leveraging the conversations to their own purposes. Social media is deemed as a "doubleedged sword" because social media can build and destroy a brand's credibility and reputation instantaneously (Odhiambo \& Adhiambo, 2012). Some brands resist from investing in social media engagement as they are unable to see the quantifiable ROIs of Twitter (Eckstein, 2018). Hence, some brands may think Twitter is not a worthy investment.

Despite the platform's bad press and seemingly back-to-back privacy scandals in the past year, Facebook's company earning sheet for Q4 2018 shows that the SNS has exceeded its revenue expectations and has seen improved user growth (Gartenberg, 2019). It was found that informative and entertaining content were able to significantly increase engagement 
level (Cvijikj \& Michahelles, 2013). Through the responses, likes and comments, users are inadvertently creating social media content for brands and facilitating interaction for other users (Dolan, Conduit, Fahy, \& Goodman, 2016). Organic reach on the platform had declined dramatically over the last few years which forces many to question the viability of organic posting (Eckstein, 2018). Another challenge is the general trend of consumer dynamics to mostly observe as a small percentile of these users will actively participate in conversations (Mazza \& Palermo, 2018).

Many brands these days prefer to have a better organic reach with their target demographic through YouTube (Marshall, 2014). Since YouTube has a comparatively longer video format than Twitter and Facebook, is easier for brands to convey information about themselves, even though the video's main focus is on the user (Smith, Fischer, \& Yongiian, 2012). The platform maybe facing some challenges due to Instagram's newest video feature. With the launch of Instagram Live and IGTV, Instagram's latest feature was made available as a standalone app (Newton, 2018). According to a survey by State of Video Marketing 2018, $41 \%$ of marketers have used Instagram videos and out of those who used it, $78 \%$ of them had found it to be an effective strategy (Wyzowl, 2018).

The IPA Model was introduced by an American social psychologist by the name of Robert Freed Bales who pioneered the systematic technique of group observations as well as a way of gaging the interaction process (Smith, 2008). The purpose of the IPA model is to enable the author to recognize and record the nature of each act, in accordance to the model (Savolainen, 2015). The model has been utilized and tested in online communication environments. A study used the IPA as a basis to content-analyse tweets made by media organizations and the results show that the media organizations posted tweets that were more task-oriented than socioemotional (Zhang, Tao, \& Kim, 2018; Lin \& Peña, 2011). However, the model has been criticised for being unable to mediate input and output states of group interactions due to appropriateness of existing methodologies for measuring group process in task-oriented groups and general issues of research strategy (Hackman \& Morris, 1975).

Content analysis is described as technique of analysing verbal, written or messages communicated visually (Cole, 1988). The term is also defined as a research method of collecting data and making transposable as well as valid inferences to its context (Krippendorff, 2018). The purpose of the research method is to attain the outcome of an analysis based on concepts describing the phenomenon and it is carried out to build upon an existing model (Elo \& Kyngäs, 2008). The research process requires the researcher to carry out the analysis based on the rules formulated and the researcher typically analyses the data with no selective insights and biased preconceived notions on the matter discussed (Kassarjian, 1977).

The company is operated by Rihanna and her team, made up of her closest group of friends as well as business partners (Levy, 2018). Under the brand's umbrella, Rihanna has multiple business and projects that are operated under the trademark of "Fenty". Fenty Puma's extensive fashion line was introduced in 2016 and it featured athleisure-styled streetwear and sneakers (Nnadi, 2016).

Another well-known Fenty endeavor, Savage x Fenty, was launched in May 2018 and featured 90 pieces of accessories, lingerie and sleepwear, available in various colours and sizes $(\mathrm{Hu}, 2018)$. Since its launch, Fenty Beauty has paid great attention to creating a strong online presence. Within the first month, almost 80,000 influential posts about the brand were posted across different platforms (Sharma, 2018). As of June 2019, the brands have over 9,375,000 
followers and subscribers across four social media platforms. Fenty Beauty's social media team ensures that the brand's social media account stay active by posting several times a day and almost every day of the week.

\section{METHODOLOGY}

Qualitative research method is used in the present study and is defined as a collection of results in non-standardized data demanding classification into categories, based on meanings expressed through words (textual or spoken) and images (Saunders, Lewis, \& Thornhill, 2016). Content analysis enables the author to detect media users' positive and negative attitudes towards the brand (ibid). It is an unobtrusive form of analysing human interactions, and it provides great insight into the complexities of human thought, language and behaviour (Colorado State University, n.d.). The data collected for the research is primarily collected from the four social media platforms, Instagram, Twitter, Facebook and YouTube.

Purposive sampling method is utilized to conduct the study. Purposive sampling method is the deliberate choice of a participant, or in the case of this research, data, due to the qualities, it possesses (Etikan, Musa, \& Alkassim, 2016). The data sample for the present study was collected from the first five most liked comments of social media posts made on Fenty Beauty's official social media accounts. The duration of 17 March 2019 to 6 April 2019 was selected because the brand had announced that they were restocking a fan favourite product, Body Lava Luminizer on the 21 March 2019 (Fasanella, 2019). The brand had also launched their new line of Sun Stalk'r Instant Warmth Bronzer on 29 March 2019 (Bowenbank, 2019).

The data collection procedure for the present study required the researcher to collect two weeks of social media posts made by the brand, whereby the five most liked comments made on the posts were collected. The researcher screenshots each social media post and tabulates according to the four platforms studied. The following step was to identify the characteristic of the social media posts and tabulate it. Once completed, the findings weill be discussed.

Internet-mediated observation method and Interaction Process Analysis (IPA) Model coding scheme were applied in the present study. Internet-mediated observation requires the researcher to collect data from an online community by mode of observing. (Saunders, Lewis, $\&$ Thornhill, 2016). The coding scheme adopted from Savolainen (2015) coding functions, who used Bales' IPA coding scheme to fit the researcher's requirements (see Table 1).

Based on the data collected, the analysis of the social media posts will be done in accordance to the IPA Model coding scheme. The data will be tabulated and identified according to the twelve codes from the data collected, the findings will be thoroughly explained and analyses to see if Fenty Beauty's online marketing strategy fits the description and characteristics of the social identity theory. 


\section{Table 1: The IPA Model Coding System}

\begin{tabular}{|c|c|}
\hline $\begin{array}{l}\text { Functional area of user } \\
\text { interaction }\end{array}$ & Interaction Process Category \\
\hline Task: questions & $\begin{array}{l}\text { 1. Asks for information, orientation, repetition, confirmation. } \\
\text { 2. Asks for opinion, analysis, evaluation, expression of feeling. } \\
\text { 3. Asks for suggestions, possible ways of action or direction. }\end{array}$ \\
\hline Task: attempted answers & $\begin{array}{l}\text { 4. Gives information, orientation, repeats, clarifies, confirms. } \\
\text { 5. Gives opinion, analysis, evaluation, wishes, expresses feelings. } \\
\text { 6. Gives suggestions, gives direction, implying autonomy } \\
\text { towards others. }\end{array}$ \\
\hline Socioemotional: Positive & $\begin{array}{l}\text { 7. Agrees, shows passive acceptance, understands, concurs, } \\
\text { complies with the task. } \\
\text { 8. Shows tension release, laughs, jokes or shows satisfaction } \\
\text { towards others. } \\
\text { 9. Shows solidarity, seems friendly, raises the status of others, } \\
\text { offers help and rewards to others. }\end{array}$ \\
\hline Socioemotional: Negative & $\begin{array}{l}\text { 10. Disagrees, shows passive rejection and withholds help. } \\
\text { 11. Shows tension, withdraws out of field or asks for help. } \\
\text { 12. Shows antagonism, seems unfriendly, deflates other's } \\
\text { reputation, defends self in an argument. }\end{array}$ \\
\hline
\end{tabular}

\section{FINDINGS}

Table 2 below shows the results of followers' reaction to Fenty Beauty's posts on their official Instagram account. Task-oriented responses had the highest score as followers mostly gave opinions (Code 5) (53.19\%, 125 of 235). For positive socioemotional, followers' mostly exhibited signs of showing solidarity (Code 9$)(60 \%, 54$ of 90). Followers exhibited signs of negative socioemotional responses, under the Code 10 (disagrees) (40\%, 4 of 10) and Code Act 12 (shows antagonism) (40\%, 4 of 10 ).

Table 2: Followers Reaction on Fenty Beauty's Post

\begin{tabular}{|c|c|c|c|c|}
\hline IPA Coding Scheme & Number of followers reaction & Percentage (\%) & Total & Percentage (\%) \\
\hline 1 - Ask for information & 43 & 12.84 & \multirow{6}{*}{235} & \multirow{6}{*}{70.15} \\
\hline 2 - Ask for opinion & 11 & 3.28 & & \\
\hline 3 - Ask for suggestion & 3 & 0.90 & & \\
\hline 4 - Give information & 34 & 10.15 & & \\
\hline 5 - Give opinion & 125 & 37.31 & & \\
\hline 6 - Give siggestion & 19 & 5.67 & & \\
\hline 7 - Agrees & 13 & 3.88 & \multirow{3}{*}{90} & \multirow{3}{*}{26.87} \\
\hline 8 - Show tension release & 23 & 6.87 & & \\
\hline 9- Show solidarity & 54 & 16.12 & & \\
\hline 10 - Disagrees & 4 & 1.19 & \multirow{3}{*}{10} & \multirow{3}{*}{2.99} \\
\hline 11 - Show tension & 2 & 0.60 & & \\
\hline 12 - Show antagonism & 4 & 1.19 & & \\
\hline
\end{tabular}


Table 3: Social media engagement for Instagram, Twitter, Facebook and YouTube

\begin{tabular}{|c|c|c|c|c|}
\hline Engagement & Instagram & Twitter & Facebook & YouTube \\
\hline Likes & $5,550,492$ & 352,567 & 12,154 & 217,651 \\
\hline Views & $9,395,781$ & & & 7,200 \\
\hline Retweets & & 59,714 & & \\
\hline Shares & & & 960 & \\
\hline Comments & $\mathbf{6 0 , 9 9 4}$ & $\mathbf{6 , 9 5 5}$ & 1,296 & 314 \\
\hline Total & $\mathbf{1 5 , 0 0 7 , 2 6 7}$ & $\mathbf{4 1 9 , 2 3 6}$ & $\mathbf{1 4 , 4 1 0}$ & $\mathbf{2 2 5 , 1 6 5}$ \\
\hline
\end{tabular}

Table 3 shows the summary of Fenty Beauty's social media engagement across four platforms namely (Instagram, Twitter, Facebook and YouTube). Instagram had the highest number likes and comments at 5,550,492 and 60,994 respectively, across all four platforms.

\section{DISCUSSIONS AND CONCLUSIONS}

It was found that most of the engagement carried out by the brand's followers are mostly task-oriented responses. In terms of positive socioemotional responses, follower's mostly showed solidarity. Followers exhibited signs of negative socioemotional responses, mostly identified as disagreement and showing antagonism. The brand's official Instagram account had the highest number of likes and comments compared to the other social media platforms. Many researchers believe that the frequency of 'likes' and 'comments' are valuable indicators to show the brand's follower engagament on the app (Erkan, 2015; De Vries, et al., 2012; Hoffman \& Fodor, 2010). Followers' of Fenty Beauty primarily demonstrated positive socioemotional responses on Instagram. Followers' mostly showed signs of solidarity. According to Tajfel's explanation of the social identity theory, it is stated that a group's social identity is derived from their knowledge of their social group membership "together with the emotional significance attached to that membership" (Tajfel, 1974; Zeugner-Roth, Žabkar, \& Diamantopoulos, 2015). Thus, Fenty Beauty's followers' reactions to posts on their official Instagram account are identified and categorized as in-group.

The follower's reaction to Fenty Beauty's tweets were mostly identified as task-oriented responses. Positive socioemotional responses displayed by the brand's followers mostly showed solidarity. This is the case because followers are most likely to reply with positive socioemotional responses than negative socioemotional responses as they are interested in enhancing their self-presentation on Twitter (Lin \& Peña, 2011). In a study conducted to understand how and why people use Twitter, it was found that the application increases chances to maintain connections as well as exchanges social support with followers (Zhao \& Rosson, 2009). Conversely, the negative socioemotional responses exhibited by followers mostly show them expressing signs of tension. Followers' of Fenty Beauty mostly demonstrated positive socioemotional responses on Twitter. According to Jenkins (2014), social categorisation produces social identity, which generates social comparison, which ultimately create positive (in-group) or negative (out-group) evaluation of self or group (Jenkins, 2014). Hence, through comparison, Fenty Beauty's followers' reactions to posts on their official Instagram account are categorized as in-group. 
The followers' reaction to Fenty Beauty's posts on their official Facebook account are mostly task-oriented responses. According to Amaya (2015), a primary function found when users communicate in groups was the information provided to other members through opinions, suggestions and orientations. In terms of positive socioemotional responses, the brands follower's mostly showed solidarity. In contrast, followers exhibited signs of negative socioemotional responses, mostly identified as showing tension.

Facebook followers' of Fenty Beauty primarily demonstrated positive socioemotional responses. According to a study conducted on organizational socialization through social identity theory, identification of a person is similar to the identification of a group, in a sense that one person partly defines the group in terms of a social referent (Ashforth \& Mael, 1989). In addition, the study found that most of the engagement carried out by the brand's followers are mostly to give suggestions. Positive socioemotional responses displayed by the brand's followers were mostly showing solidarity. In contrast, negative socioemotional responses, followers mostly exhibited signs of tension. Although the platform demonstrated more negative than positive responses, the platform may change for the better in the future. A study justified the present findings, given experience and time, computer-mediated environments will be conducive to the exchange of social information, despite the decreased availability of nonverbal cues. People may become more socioemotional and exchange more positive socioemotional online interactions as time goes on (Walther \& Burgoon, 1992).

The interactions that occurred on Fenty Beauty's official YouTube account were primarily positive. Most of the followers' interactions were identified as task-oriented responses. In a journal article explaining the social identity theory by Stets and Burke (2000), they believe that the result of self-categorization is an accentuation of resemblances usually occurs when beliefs and values, attitudes and other factors that are thought to be correlated to the group is categorized into one (Stets \& Burke, 2000). In this case, since followers mostly demonstrated positive socioemotional, hence, Fenty Beauty's followers' reactions to posts on their official YouTube account are categorized as in-group.

According to the results found in the present study, Instagram has the significantly highest social media engagement with followers. The finding is justified as the brand's official Instagram account has the highest number of followers and number of posts posted. In a study to learn how Instagram is used to market tourism destinations. Hanan and Putit (2013) state that the platform is successful because it is deemed as one of the best most used picture-based social media applications globally. It was observed that all Instagram posts had hashtags based on the product promoted on each post. The use of hashtags help people search for the content they want, and in turn, guarantees a successful relationship between businesses and Instagram. Based on the findings, Instagram is the most effective SNS that accommodates and encourages the interaction between Fenty Beauty and their followers.

The final proposed conceptual framework was modified based on the findings of the present research as per Figure 2. The followers' reaction to Fenty Beauty's posts on their official social media pages demonstrated that most of the interactions that were carried out were primarily positive socioemotional responses. 


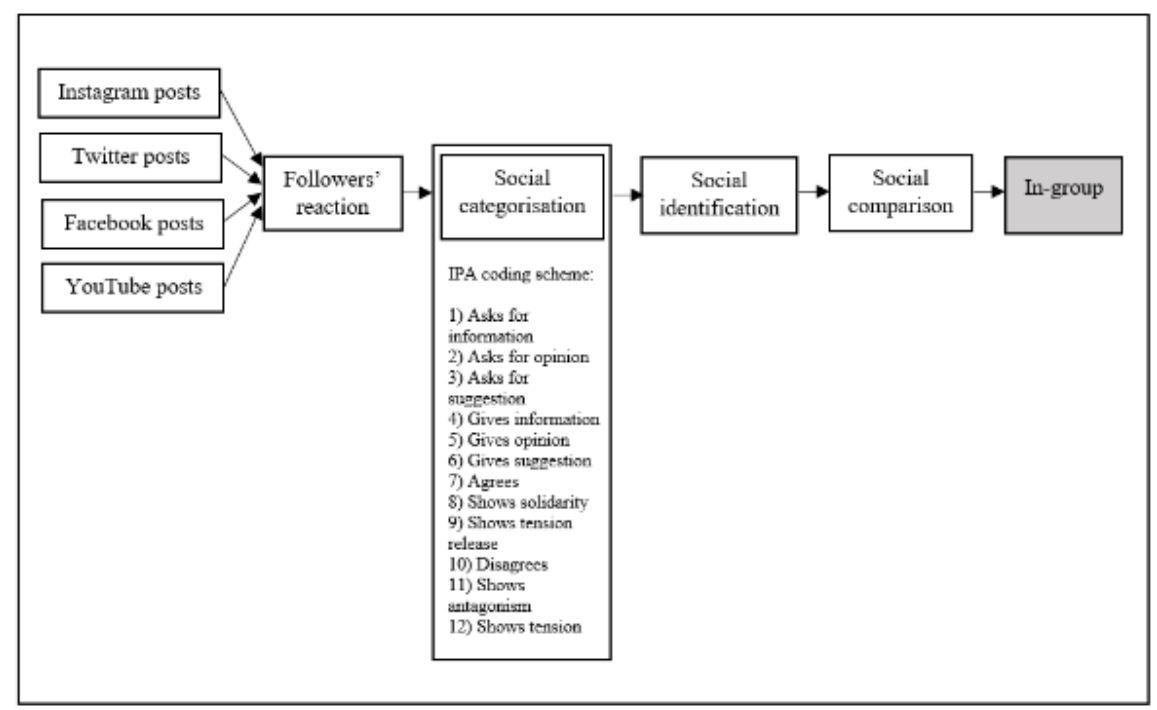

Figure 2: Modified Final Proposed Conceptual Framework

Therefore, for future research can build upon this research by comparing the social media strategies utilized by other cosmetic brands. Researcher can analyse the best brand to interact with their following to be able to come up with a more precise and comprehensive conclusion by the end of the study. Additionally, future researchers can study how cosmetic brands interact with their followings on other various social media platform. A similar research concept can be adapted by using a quantitative research method. This would allow researchers to receive feedback directly from followers of a brand instantly.

To conclude, the follower's reaction to Fenty Beauty's posts on their official Instagram, Twitter, Facebook and YouTube account were mostly task-oriented responses. For Instagram, Twitter and Facebook, followers' mostly demonstrated positive socioemotional responses. YouTube showed results of higher negative socioemotional responses. The followers' of the brand are classified as in-group. Instagram has proven to be the best platform to engage with followers. In brief, Fenty Beauty is a great brand to set as a benchmark when it comes to social media engagement.

\section{REFERENCES}

Abouarrage, N. (2017, October 31). Rihanna's fenty beauty earned even more attention on social media than kylie cosmetics. W Magazine. https://www.wmagazine.com/story/ rihanna-fenty-beauty-social-media

Amaya, B. (2015). A case study investigation of the shared identity of the Papua New Guineans against domestic violence Facebook group. (Unpublished PhD Thesis).Texas Tech University, USA.

Ashforth, B. E., \& Mael, F. (1989). Social identity theory and the organization. Academy of Management Review, 14 (1), 20-39.

Axel Bruns. (2016). "User-generated content" in: The international encyclopedia of communication theory and philosophy. Retrieved from http://snurb.info/files/2016/ User-Generated\%20Content.pdf 
Bailis, R. (2017, October 18). The Fenty craze: How other beauty brands can compete online. Digital Commerce 360. Retrieved from https://www.digitalcommerce360.com/2017/10/18/ the-fenty-craze-how-other-beauty-brands-can-compete-online/

Bales, R. F. (1951). Interaction process analysis: a method for the study of small groups. Boston: Addison-Wesley Press, Inc.

Barnhart, B. (2018, October 16). The complete guide to social media and the beauty industry. SproutSocial. Retrieved from, https://sproutsocial.com/insights/social-media-and-beautyindustry/

Bergström, T., \& Bäckman, L. (2013). Marketing and PR in social media: How the utilization of Instagram builds and maintains customer relationships. (Unpublished Dissertation.) Department of media studies, faculty of humanities, stockholm university.

Bowenbank, s. (2019, March 29). Rihanna is expanding shade diversity to Fenty Beauty's First-Ever Bronzer. Elle. Retrieved from, https://www.elle.com/beauty/makeup-skincare/a26985583/rihanna-fenty-beauty-launch-bronzer/

Coady, M. (2018, April 27). The beauty industry faces its biggest challenge, ever. The Robin Report. Retrieved from, https://www.therobinreport.com/the-beauty-industry-faces-itsbiggest-challenge-ever/

Cole, F. L. (1988). Content analysis: process and application. Clinical Nurse Specialist, 2 (1), 53-57.

Colorado State University. (n.d.). Content analysis. Writing@CSU. Retrieved from, https:// writing.colostate.edu/guides/page.cfm?pageid=1318\&guideid=61

Constantinides, E. (2009). Social media / web 2.0 as marketing parameter: an introduction. In Proceedings of the 8th International Congress Marketing Trends (pp. 20-21) http:// www.escp-eap.net/conferences/marketing/pap.html.

Cvijikj, I. P., \& Michahelles, F. (2013). Online engagement factors on Facebook brand pages. Social Network Analysis and Mining, 3, 843-861. https://doi.org/10.1007/s13278-013-0098-8

Dolan, R., Conduit, J., Fahy, J., \& Goodman, S. (2016). Social media engagement behaviour: a uses and gratifications perspective. Journal of Strategic Marketing, 24 (3-4), 261-277.

Eckstein, M. (2018, June 7). Social media engagement is the new social media marketing: how to do it well. Buffer. Retrieved from, https://buffer.com/library/social-media-engagement

Elo, S. \& Kyngäs, H. (2008). The qualitative content analysis. Journal of Advanced Nursing, 62 (1), 107-115.

Etikan, I., Musa, S. A., \& Alkassim, R. S. (2016). Comparison of convenience sampling and purposive sampling. American Journal of Theoretical and Applied Statistics, 5(1), 2-3.

Fahy, P. J. (2006). Online and face-to-face group interaction processes compared using Bales' interaction process analysis (IPA). European Journal of Open, Distance and E-Learning, 9 (1). http://www.eurodl.org/materials/contrib/2006/Patrick_J_Fahy.htm

Farook, F. S., \& Abeysekara, N. (2016). Influence of social media marketing on customer engagement. International Journal of Business Management Invention, 5 (12), 115-125.

Fasanella, K. (2019, March 20). Fenty beauty restocks body lava in new limited-edition shades. Allure. Retrieved from, https://www.allure.com/story/fenty-beauty-body-lavaback-in-stock

Forbes, K. (2016). Examining the beauty industry's use of social influencers. Elon Journal of Undergraduate Research in Communications, 7 (2), 78-87. 
Gartenberg, C. (2019, January 30 ). Facebook keeps growing despite scandals and privacy outrage. The Verge. Retrieved from, https://www.theverge.com/2019/1/30/18204186/ facebook-q4-2018-earnings-user-growth-revenue-increase-privacy-scandals

Gong, X. (2014). Strategic Customer Engagement on Instagram: A Case of Global Business to Customer (B2C) Brands. (Unpublished Master Thesis). KTH Royal Institute of Technology, Stockholm, Sweden.

Hackman, J. R., \& Morris, C. G. (1975). Group tasks, group interaction process, and group performance effectiveness: A review and proposed integration. Advances in Experimental Social Psychology, 8, 45-99

$\mathrm{Hu}, \mathrm{C}$. (2018, May 11). From fenty beauty to savage: the secrets to Rihanna's business success. Billboard. Retrieved from, https://www.billboard.com/articles/business/8455343/rihannabusiness-success-fenty-beauty-savage

Hutter, K., Hautz, J., Dennhardt, S., \& Füller, J. (2013). The impact of user interactions in social media on brand awareness and purchase intention: The case of MINI on Facebook. Journal of Product \& Brand Management, 22 (5/6), 342-351..

Jaakonmäki, R., Müller, O., \& vom Brocke, J. (2017). The impact of content, context, and creator on user engagement in social media marketing. In Hawaii International Conference on System Sciences. https://doi.org/10.24251/HICSS.2017.136

Jenkins, R. (2014). Social identity (3rd edition). New York: Routledge.

Kassarjian, H. H. (1977). Content analysis in consumer research. Journal of Consumer Research, 4, (1), 8-18, https://doi.org/10.1086/208674

Krippendorff, K. (2018). Content analysis: An introduction to its methodology. New York: Sage publications.

Levy, L. (2018, August 13). A guide to Rihanna's business partners and best friends. Fader Retrieved from: https:/www.thefader.com/2018/08/13/a-guide-to-rihannas-businesspartners-and-best-friends

Lin, J. S., \& Peña, J. (2011). Are you following me? A content analysis of TV networks' brand communication on Twitter. Journal of Interactive Advertising, 12 (1), 17-29.

Marshall, C. (2014, May 6). YouTube Smashes Facebook when it comes to brand engagement [Infographic]. Turbular Insights. Retrieved from : https://tubularinsights.com/youtubefacebook-brand-engagement/

Mazza, B. \& Palermo, A. (2018). Social media content for business and user engagement on Facebook. ESSACHESS-Journal for Communication Studies, 11 (1), 49-73.

Mueller, G. (n.d.). Why Twitter is the ideal platform for engagement. ConvinceEConvert Retrieved from: https://www.convinceandconvert.com/social-media-strategy/twitterengagement/

Newton, C. (2018, June 20). Instagram announces IGTV, a standalone app for longer videos. The Verge Retrieved from : https://www.theverge.com/2018/6/20/17484436/instagramigtv-video-app-launch

Nnadi, C. (2016, February 13). Fall 2016 ready-to-wear. Vogue. Retrieved from https://www. vogue.com/fashion-shows/fall-2016-ready-to-wear/fenty-puma

Odhiambo, M., \& Adhiambo, C. (2012). Social media as a tool of marketing and creating brand awareness. (Unpublished Barchelor of Business Administration Disertation). University of Applied Sciences, Vaasa, Finland 
Phillips, A. (2018, December 4). 21 Tips to massively increase instagram engagement in 2019. Falcon.io. Retrieved from: https://www.falcon.io/insights-hub/topics/social-mediastrategy/21-tips-increase-instagram-engagement/

PR Newswire. (2018, November 14). Global beauty and personal care products market 20182025: Increasing adoption of augmented reality in the beauty industry. PR Newswire. Retrieved from: https://www.prnewswire.com/news-releases/global-beauty-andpersonal-care-products-market-2018-2025---increasing-adoption-of-augmented-realityin-the-beauty-industry-300750230.html

Rajput, N. (2016, July). Cosmetics market by category (skin \& sun care products, hair care products, deodorants, makeup \& color cosmetics, fragrances) and by distribution channel (general departmental store, supermarkets, drug stores, brand outlets) Global Opportunity Analysis. Allied Market Research. Retrieved from https://www. alliedmarketresearch.com/cosmetics-market

Reuters. (2018, March 13). Global Cosmetics Products Market expected to reach USD 805.61 billion by 2023 - Industry Size \& Share Analysis. Reuters. Retrieved from: https://www. reuters.com/brandfeatures/venture-capital/article?id=30351

Robehmed, N. (2018, July 11). How 20-year-old Kylie Jenner built a $\$ 900$ million fortune in less than 3 years. Forbes. Retrieved from: https://www.forbes.com/sites/ forbesdigitalcovers/2018/07/11/how-20-year-old-kylie-jenner-built-a-900-million-fortunein-less-than-3-years/\#f2787aaaa62c

Saunders, M., Lewis, P., \& Thornhill, A. (2016). Research methods for business students. Harlow: Pearson .

Savolainen, R. (2015). The role of emotions in online information seeking and sharing: A case study of consumer awareness. Journal of Documentation, 71(6), 1203-1227.

Sharma, T. (2018, March 7). The fenty impact: what beauty marketing can learn from Rihanna. Medium. Retrieved from: https://medium.com/@tanvi00sharma/the-fenty-impact-whatbeauty-marketing-can-learn-from-rihanna-9f12dea11c40

Shen, B., \& Bissell, K. (2013). Social media, social me: a content analysis of beauty companies' use of Facebook in marketing and branding. Journal of Promotion Management, 19 (5), $629-651$.

Shi, H. (2018). Breaking the Internet: A study of generation $\mathrm{Z}$ and viral marketing. (Unpublished Thesis). University of Texas at Austin. USA.

Simpson, G., \& Craig, E. (2018, May 23). How digital has changed cosmetics and what this means for consumers. Campaign Retrieved from: https://www.campaignlive.co.uk/article/ digital-changed-cosmetics-means-consumers/1463485

Smith, A. N., Fischer, E., \& Yongjian, C. (2012). How does brand-related user-generated content differ across YouTube, Facebook, and Twitter? Journal of Interactive Marketing, 26(2), 102-113.

Smith, M. K. (2008). Robert Freed Bales, group observation and interaction processes. Infed. Retrieved from: http://infed.org/mobi/robert-freed-bales-group-observation-andinteraction-processes/

Soboleva, A., Burton, S., \& Khan, A. (2015). Marketing with Twitter: Challenges and opportunities. In. Management Association, I. (Ed.) Digital marketing and consumer engagement: Concepts, methodologies, tools, and applications (pp. 695-732). Pennsylvania: IGI Global. http://doi:10.4018/978-1-5225-5187-4 
Statista. (2018). Number of monthly active Instagram users from January 2013 to June 2018 (in millions). Statista. Retrieved from: https://www.statista.com/statistics/253577/numberof-monthly-active-instagram-users/

Stets, J. E., \& Burke, P. J. (2000). Identity theory and social identity theory. Social Psychology Quarterly, 63, (3), 224-237.

Tajfel, H. (1974). Social identity and intergroup behaviour. Social Science Information, 13(2), 65-93.

Triberr. (n.d.). FAQ (What is an Instagram Shadowban?). Triberr Retrieved from: https:// triberr.com/instagram-shadowban-tester

Wall, S. (2019, January 22). 3 lessons in social media brilliance from Rihanna. PR Daily Retrieved from: https://www.prdaily.com/3-lessons-in-social-media-brilliance-fromrihanna/

Walther, J. B., \& Burgoon, J. K. (1992). Relational communication in computer-mediated interaction. Human Communication Research, 19 (1), 50-88.

Walters, J. (2018). "Finally some diversity": An exploration into the publics' perceptions of the 'Fenty Beauty'campaign in relation to how it challenges the lack of diversity in the mainstream Westernized beauty industry. (Unpublished Final Year Project). Cardiff Metropolitan University.

Wirtz, J. D. (2013). Managing brands and customer engagement in online brand communities. Journal of service Management, 24 (3), 223-244., 4.

Wyzowl. (2018). Survey: The state of video marketing 2018. Wyzowl Retrieved from: https:// www.wyzowl.com/video-marketing-statistics-2018/

Zelealem, M. (2017). Diversity in the beauty industry. Digital Common @ Loyola Marymount University and Loyola Law School. https://digitalcommons.lmu.edu/honors-research-andexhibition/2017/section-02/12/

Zeugner-Roth, K. P., Žabkar, V., \& Diamantopoulos, A. (2015). Consumer ethnocentrism, national identity, and consumer cosmopolitanism as drivers of consumer behavior: A social identity theory perspective. Journal of International Marketing, 23(2), 25-54.

Zhang, X., Tao, W., \& Kim, S. (2018). A comparative study on global brands' micro blogs between China and USA: Focusing on communication styles and branding strategies. International Journal of Strategic Communication, 8(4), 231-249.

Zhao, D., \& Rosson, M. B. (2009). How and why people Twitter: the role that micro-blogging plays in informal communication at work. In Proceedings of the ACM 2009 international conference on Supporting group work, 243-252.

Zeugner-Roth, K. P., Žabkar, V., \& Diamantopoulos, A. (2015). Consumer ethnocentrism, national identity, and consumer cosmopolitanism as drivers of consumer behavior: A social identity theory perspective. Journal of International Marketing, 23(2), 25-54. 